\title{
Battlefield: Social Representations of Commercial Sex Work on Transvestite and Transsexual Females in Brazil
}

\author{
Sobre campos de batallas: Representaciones sociales del comercio sexual \\ entre mujeres auto-identificadas como transexuales y travestis brasileñas
}

\author{
Jaime Alonso Caravaca Morera ${ }^{1}$ \\ Universidad de Costa Rica, Costa Rica
}

\begin{abstract}
Objective. To analyze commercial sex work's social representations among Brazilian women who identify as transvestite or transsexual. Methods: A qualitative study with a descriptive and analytical approach based on the Theoretical Paradigm of Social Representation with a structural approach. The sample group was formed by 100 women who defined themselves as transvestite and transsexual in Santa Catarina, Brazil. The data was gathered from September to December 2016 via a questionnaire using the technique of free association of words, as well as semi-directed interviews. Results: Through both prototypical and content analysis, it was confirmed that the most likely elements that formed the core of the social representation were: violence, drugs, risk, work, sadness, prejudice, and danger. In the objectification/objectivation process of commercial sex work, the image shows a mix between daily activities in the streets - which they consider to be their battlefield - and their own feelings and experiences of vulnerability in other areas of society, starting with families, churches, schools and the like. Conclusions: By experiencing commercial sex work, female transvestite and transsexual individuals reveal how the elements that form the social representation are of paramount importance in the legitimation, legalization, and simplification of their identities.
\end{abstract}

Keywords. Social Representations, commercial sex work, transvestite, transsexual, public health.

Resumen. Objetivo: Analizar las representaciones sociales del comercio sexual entre mujeres auto-identificadas como travestis y transexuales en Brasil. Métodos: Estudio cualitativo de naturaleza descriptivo-analítico que, utilizó el Paradigma Teórico de las Representaciones Sociales con abordaje estructural como Referencial Teórico. La muestra fue constituida por 100 mujeres auto-identificadas como travestis y transexuales en Santa Catarina/Brasil. Los datos fueron recolectados de septiembre a diciembre de 2016, por medio de la utilización de un cuestionario auto-administrado que utilizó la técnica de asociación libre de palabras y, por medio de entrevistas semi-directivas. Resultados: A partir del análisis prototípico y de contenido se verificó que los elementos probables que formaron el núcleo central de la representación social fueron: violencia, drogas, riesgo, trabajo, tristeza, prejuicios y peligro. En el proceso de objetificación/objetivación de la prostitución, la imagen refleja un compaso entre sus itinerarios cotidianos en el campo de batalla y los sentimientos y vivencias de vulnerabilidad en los otros espacios institucionales de la sociedad. Conclusiones: la experiencia del comercio sexual de mujeres travestis y transexuales reveló cómo los elementos formadores de la representación social son cruciales en el proceso de legitimación, normatización y simplificación de sus identidades.

Palabras clave. Representación social, prostitución, travestis, transexuales, salud colectiva.

${ }^{1}$ Jaime Alonso Caravaca Morera. Universidad de Costa Rica, Costa Rica. Postal Adrress: 11501-2060, Universidad de Costa Rica.

E-mail: jaimealonso.caravaca@ucr.ac.cr

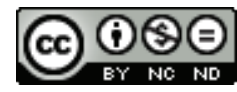

Esta obra está bajo una licencia de Creative Commons Reconocimiento-NoComercial-SinObraDerivada 4.0 Internacional. 


\section{Introduction}

Regarding the unplanned capitalist urban and socio-economic growth in cities, transsexual and transvestite ${ }^{2}$ commercial sex workers are seen as a threat to the imaginary created by common citizens. The figure of -not few- female transvestite and transsexual people who are involved in the sex trade becomes an element that undermined the paradigmatic intelligibility artificially attributed to sex, bodies, genders, and sexualities.

These women are constantly attacked by inquisitive gazes that show that they have been defined as merchants and merchandise at once thus symbolizing the fragmentation of modern society and the radical separation between eroticism, pleasure, and love (Longaray \& Ribeiro, 2016).

Apparently, the prevailing moral rigidity of our times condemns intimacy and places transvestite and transsexual people in a position associated with sin and sickness - this is what we define as the paradigm of religious damnation and medicalization of social behaviors still pervading among Latin American societies.

We believe these archaic socio-cognitive ideas remain due to the emergence of fear caused by the deterritorialization of subjectivity, which knows no boundaries because of a society that is urban, industrial, and capitalist; along with the entrance of women on different social spaces and the increase in their social rights, pointing to an idea of 'egalitarian' genders.

Semantically, the word 'prostitute' is a noun and an adjective with the power of drawing symbolic boundaries that should not be trespassed. Additionally, the word places coitus in a specific location of the city, one especially dedicated to evasion, casual sex, and transactions related to human needs (economic, spiritual, emotional, or sexual).

A trans woman or transvestite who engages in commercial sex work must always be considered the otherness, a creature who uses commercial sex work as a defense mechanism. In other words, it is seen as a nomadic person unable to get involved with her customer at an emotional level; a person who only brings order to turbulent passions and sexual desires (both her own and her client's) while running away from invisibility and exclusion (Kulick, 2008; Santos, 2015; Caravaca-Morera, \& Padilha, 2016).

The field of study created around commercial sex workers has come to give new meaning to many practices related to desires and fantasies reinforced by laws and moral expectations imposed by society. On the other hand, modernization, economic growth, booming population, and the pervasiveness of subjective thought have also affected how commercial sex work is viewed.

${ }^{2}$ In this investigation, the political discourses of gender identity affirmation were represented through two different types of women: those who define themselves as transvestite and the ones who do the same as transsexual. Since the investigators did not want to set a hierarchy between their lives and experiences, the decision was made not to use the neologism 'trans,' and instead use "transsexual" and "transvestite," to show respect, make visible and reinforce their specific characteristics, reactions, and realities. We consider that being transvestite or transsexual depends only on the self-recognition process that relates each of the participants with their group and/or political current.

Actualidades en Psicología, 32(125), 2018, 79-93 
In this sense, the commercial sex work performed by transvestite and transsexual women must be understood as a complex social phenomenon that intersects with economy, work and corporal and sexual choices: all gender-related topics.

The places where sexual trade takes place must be considered the scenarios where personal learning is constructed. They are the platform for performativity and gender reinforcement.

Nevertheless, it is a fact that almost $90 \%$ of transvestite and transsexual women in Brazil are involved in commercial sex work; little is known of its social representations and the elements that compose it because few studies have been interested in unveiling this reality (Souza, Malvasi, Signorelli, \& Pereira, 2015).

In the face of this reality, and acknowledging that the debate on commercial sex work in Brazil and other Latin American countries, developed by healthcare and nursing professionals, is limited and still permeated by strong orthodox postures, this study emerges to analyze the social representations of commercial sex work among selfidentified transvestite or transsexual women in Brazil in a structural manner.

In this sense, the theory of social representations allows to articulate the social and the cognitive (psychological) domains into a dynamic process that aims to understand the social thought from the mechanisms present in the social elaboration of what is real. Its elaboration process involves the individual as part of a double process: the representations direct their actions and are, simultaneously, modified by time and the physical contexts that finally permeate other cognitive processes and social practices.

Social representations are therefore forms of knowledge of the world, socially elaborated and shared, that allow for the allocation of giving meaning to new or known facts, contributing to processes of behavior formation and orientation of social communications (Moscovici, 1976).

In addition, Jodelete (2001) reports that shared representations build a concessional vision of reality and provide possibilities for daily action. Along the same lines, to share an idea or image is to affirm a social bond and an identity.

For this reason, according to Moscovici (2003), the meaning of social representations corresponds to a proper recurrent model of images, beliefs and symbolic behaviors with a dynamic character; that is, social representations are presented as a network of ideas, metaphors and images that articulate and provide legitimacy to the social identity.

\section{Method}

This project is a qualitative study with an analytical and descriptive nature, using the Theoretical Paradigm of Social Representations with a structural approach as theoretical reference.

\section{Participants}

The sample was consisted of 100 women from the State of Santa Catarina in southern Brazil who identified as transvestite or transsexual. This particular city was chosen since both investigators are familiar with it. 
The investigators were supported by a non-governmental organization: Associação em Defesa dos Direitos Humanos com enfoque na Sexualidade (ADEH); and the participants were identified through information provided by the organization and the methodological 'snowball' technique. Phone calls, emails and social media (especially Facebook) were valuable tools to schedule appointments with the participants, to introduce the objectives of the investigation, and gather information.

In order to participate, women needed to fulfill the following requirements: Be of legal age, possess legal Brazilian citizenship or official migratory permission to live in Brazil, identify as transsexual or transvestite, be at some point of their transition process, and at least two years' involvement in commercial sex work and sex trade in general. These requirements aimed to guarantee a true understanding of the social phenomenon under investigation.

The investigation was part of the Macro-Project: "Stories of Life and Social Representations of the sex, body, gender and sexuality among trans-identified individuals of Brazil, Canada and Costa Rica”. It was evaluated by the Ethics Committee for Research with Human Beings of the Federal University of Santa Catarina. All the regulations of the National Health committee were followed according to Resolution No 875.931/2014.

The general characteristics of the studied population are as follows: fifty-seven percent of the participants identified as transsexual females; $43 \%$ did so as transvestites. In addition, $42 \%$ of them were between 18 and 25 years old; $56 \%$ were between 25 and 35 and only $2 \%$ were over 35 years old. Eighty-five percent considered themselves heterosexual, $10 \%$ bisexual, and 5\% pansexual. Sixty-two percent of the group lived in Florianopolis, $19 \%$ in the São José region, $9 \%$ in the city of Cobrasol, $6 \%$ in Balneário Camboriu, and $4 \%$ in Palhoça.

In terms of level of schooling, $94 \%$ of the population said to have completed Elementary School, 5\% did not finish High School and 1\% did not went to School. Finally, 65\% of the women had been in the sex trade for more than 5 years and the remaining $35 \%$ had been in the sex trade for a period between 2 and 4 years.

\section{Instruments}

After authorization was granted by signing the terms of the Informed Consent, the data was collected from September to December 2016 with the aid of the following instruments:

1) Self-administered structured questionnaire using the Word Association technique, which started with the term 'Commercial sex work' (average duration of 10 minutes), 2) Half-directive and non-structured interview to investigate the social representations of commercial sex work with 12 women (explicit data saturation): Five transvestites and seven transsexual women (average duration 60 minutes).

The interviews were recorded with a digital device and then transcribed to begin the analysis of the information provided by the participants.

Regarding the first stage of data gathering stage, it is important to mention the structure of the free evocation questionnaire: First instruction: Mention the first five words that come to mind when the word 'prostitute' is uttered. Second Instruction: Number your 
answers and classify by importance, 1 being the most important word and 5 the least important one. One last task asked the participants to evaluate the feasibility of each answer. A final question was asked: Is it possible to think about prostitution without thinking of/about words $1,2,3,4$, and 5 ?

Analysis

While further studies are needed to resolve this issue, a prototypical analysis was carried out in this phase of the investigation to determine the representative elements (core, first and second periphery, and contrast elements). In this analysis, the frequencies and the mean order of evocation of utterances were tabulated in a worksheet from Apache Open Office, and the data was subsequently exported to the informative software IRAMUTEQ version 0.7. for analysis.

The prototypical analysis conducted afterwards allowed for the examination not only of the elements that constitute social representations, but also of the relationship between them through a graph. Such analysis became the main technique to obtain a connection between the elements of the representation, thus visualizing their organization.

The objective of the second stage associated to the semi directed interview was to share everyday beliefs, attitudes, values, and experiences that surround commercial sex work. Through the classical intervention techniques for this type of interview, the participants were asked to answer amply on the topic: Experiences of Transvestites and Transsexual Women Engage in Commercial sex work and Sex trade.

During each interview, a code in the form of a "Trans woman" or "Transvestite", followed by an Arabic number was assigned, so that each statement could be linked to a participant during the content analysis (also prototypical).

For this phase, the software Atlas.ti version 7.5 was used for the organization of the interviews in order to identify important patterns or repetitions relevant to the investigation, especially the grouping of ideas for the formation of families of codes (thematic elements) and counting of occurrences.

Words associated to the most significant elements of the representation (core, peripheries, and contrast zones) were re-grouped, thus building the categories according to the topics, which emerged from both free association and the interview as shown below.

\section{Results}

For most of the participants, living as a transvestite or transsexual woman only became real by "fighting" in the streets, since for them this was the place that fostered the possibility of actual physical change through extreme methods such as invasive cosmetic treatments; mainly industrial silicon in breasts, hips, and the gluteal muscles.

As explained in the Methods section, a prototypical analysis was conducted from the data gathered in the questionnaire on the frequency of the words used and the median order of evocation. This aimed to identify the most likely elements of the representational core, as well as the contrast elements and those which constitute the first and second periphery. 
Regarding the social representation on commercial sex work, 500 evocations were made using 178 different words. The average frequency of the evocations was of 8.22, the accumulated frequency was $56 \%$, and AOR was 2,83 . This means that OME words lower than 2,83 were considered to have a lower AOR*; and terms with a frequency lower than 3 were not considered for the inclusion in the quadrants in the following diagram.

The diagram of four quadrants represents the four dimensions of the social representation structure of commercial sex work. The upper left quadrant shows the words with highest frequency $(F>8.22)$ and low middle evocation (those who were quickly evoked and / or categorized as the most important by the participants).

This means that the concepts of violence, drugs, risk, work, sadness, prejudice, and danger are the most likely elements that form the core of the social representation.

In this first group, the concepts of 'violence and drugs' are presented as the most important according to their hierarchies. The importance of these terms is also configured by their

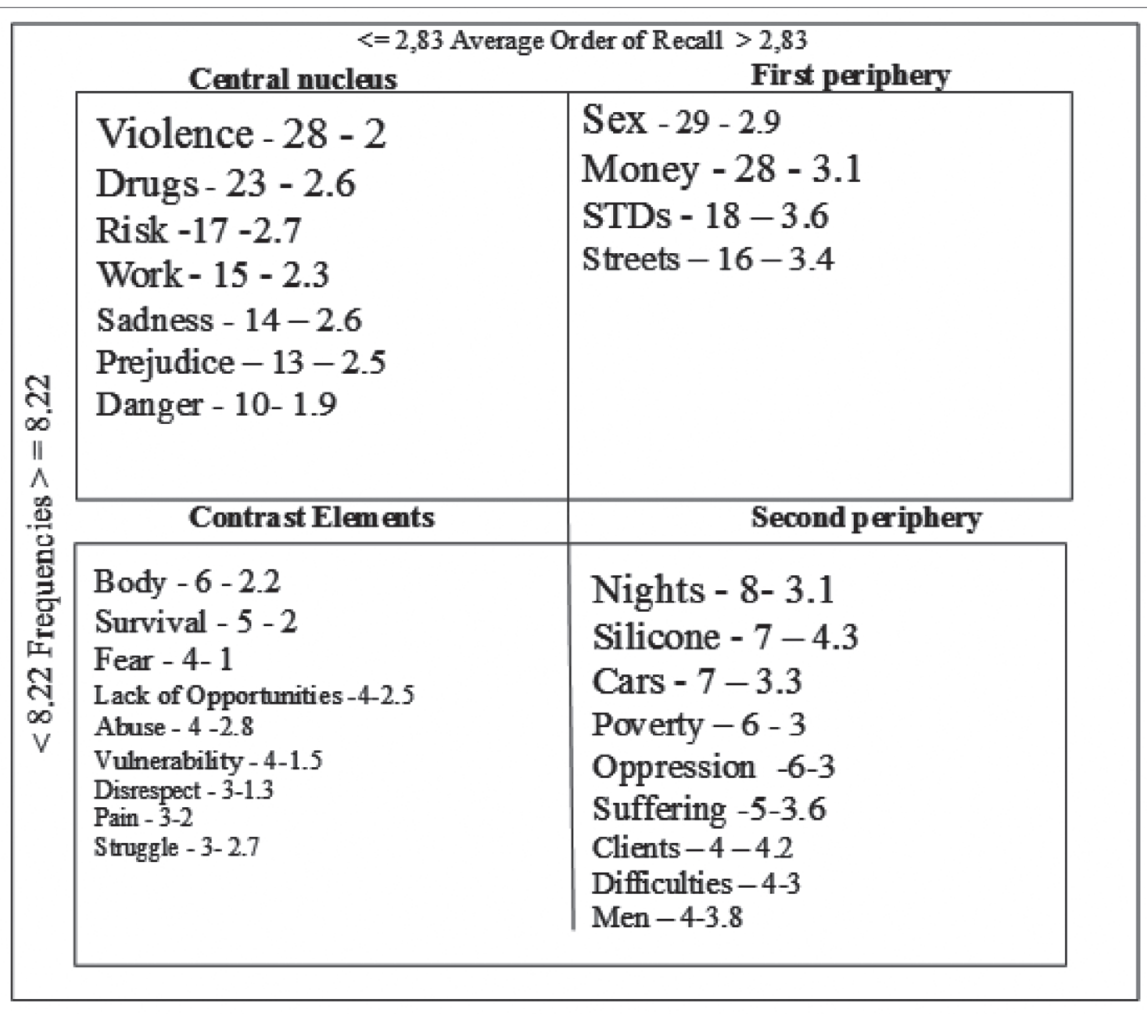

Figura 1. Quadrants Diagram - Prototype Analysis of the representation of commercial sex work on Transvestite and Female Transsexual, Florianópolis, 2017. Diagram of four quadrants, which represents the four dimensions of the social representation structure of commercial sex work. The first quadrant on the upper left shows the high frequency words $(F>8.22)$ and low middle evocation (those who were quickly evocated and/or categorized as the most important by the participants). 
prominence and how they complement each other with other elements that overlap in negative emotional and working terms: risk, work, and danger in one hand, sadness and prejudice in the other. Therefore, it is safe to say that the core is constituted by elements that are functional, complimentary, and harmonious.

Considering the core as the result of the collective memory and the set of norms to which the group of transvestite and transsexual women claim to adhere, it seems to become an absolute group of prescriptions and life experiences.

In this representation, the core reports commercial sex work as two realities shown on the daily 'battles' experienced by transvestite and transsexual women. In addition, the core relates directly to the actual possibility of understanding commercial sex work as a phenomenon that envelopes situations and activities that the women who were part of this study must deal with on a daily basis.

We may also say that the evocated term 'violence' comes from the daily reality these women face: inequality, feelings of helplessness, male superiority and female discrimination still permeating society - cis, transvestite or transsexual women who engage in commercial sex work as stated by the participants, as shown below.

By making appointments, you encounter three constant dangers: being either killed, raped or beaten... the last two have already bappened to me, now I just have to die (Transvestite Woman 1).

I live a hard life as a transvestite, started walking the streets since I was a little girl. In commercial sex work, you learn a lot, it is a school; death becomes a companion, you could die at any time (Transvestite Woman 3).

I met several transvestite women and ended up getting into this world (commercial sex work). When a fellow commercial sex worker was murdered on the street right next to me I felt so much fear, but you have to get used to living with this, there is no choice (Transsexual Woman 4).

Regarding drug usage as the second most frequent element with a minor AOR in the designed representation, all twelve women who were interviewed also stated that drugs are part of life in the streets; or the "battle field" as they call it.

Due to rejection both at home and in the labor market, many transvestite and transsexual women resort to drugs looking for reassurance and the necessary strength to deal with every day adversities in the world of commercial sex work. Chemical dependence seems to be a common denominator in this population:

Aaaabh! The only way to take all this is using drugs, that is the only way you can give yourself. I use drugs, I have smoked maribuana for a long time; I think. I do it to keep from doing crack and cocaine (Transsexual Women 7).

In commercial sex work drugs come to you, you do not go to them. Drugs come through clients, other commercial sex workers, and random people on the street. You become exposed and there is no choice but to use them (Transsexual Woman 5).

I have already used crack, did it for a while. Now I do not play with it but I still inhale cocaine from time to time. You have to use drugs to endure the night. You see, in reality nobody lives like this without inhaling or smoking (Transsexual Woman 12). 
The previous statements show that most participants associated drugs with the seduction of the night and alleys cast over those who embrace commercial sex work. At the same time, it becomes the necessary fuel to make it through in the sex trade.

The content shown in the core points to a consensus in the day-to-day working life. Violence, drugs usage, risk, danger, and sadness for transvestite and transsexual women who enter commercial sex work comes from their interactions with clients, peers, society in general, and the police.

By associating the terms that form the core, it becomes clear how the empirical knowledge of a transvestite and transsexual women are structured through the objectification/ objectivation process.

In the objectification/objectivation process of commercial sex work, the image reflects a relation between their daily activities in the streets or "battlefield", as they call it, and the feelings and experiences of vulnerability in other social institutions such as school, spiritual support organizations, and social welfare institutions.

The right upper quadrant contains the possible elements of the first representational periphery with the words frequently mentioned and higher AOR at the same time. This means that, for the participants in the study, these elements were not so essential when thinking of commercial sex work as work activity.

Hence, the terms sex, money, sexually transmitted infections, and streets would form part of the first periphery of this representation. These elements reveal a complimentary positioning versus what is happening (sex), the goal (earning money), the place where this takes places (the street) and a reality they must deal with (sexually transmitted diseases.)

In the third quadrant (lower left), the contrast zone shows elements quickly evocated but frequently lower than average: body, survival, fear, and lack of opportunities. These terms reinforce the representation of commercial sex work that the participants report. The evocations, instead of designing a possible opposition, support the elements of the core and show the affective/subjective characteristics possibly because of their daily activities.

Consequently, different to the classic idea of contrast as an opposition or counter-position to the image presented in the core on this study, the terms shown are complimentary to the terms from the core. Such elements reinforce a negative attitude toward the stimuli under investigation supported by expressions of fear, survival, lack of opportunities, pain, constant fight, and disrespect.

Finally, the second periphery in the fourth quadrant (lower right) exhibits the least frequent elements with a higher evocation average: Night, silicon, cars, poverty, and oppression. All these terms support the objectified aspect that characterizes the representation designed while fostering and offering stability to the most core-related elements of it.

On the other hand, the analytic image of similarity of the elements of social representations shows, as indicators of its structure, the size of the colored vertices that is proportional to the frequency of words, and the edges that show the strength of co-occurrence between 
its concepts. In other words, by looking at the figure below, the reader can identify the level of connection of the elements of the different factors of the representation investigated.

The figure 2 verifies the three-interconnected axis, the axes' names are: Sex, Violence, and Money. The first axis, 'Sex', is strongly related to the concepts of 'Work' and 'Poverty' (thicker line) and juxtaposed to the terms 'Survive and 'Profession.'

The latter can be the result of 'Poverty', or limited ways of economic improvement, that forces transvestite and transsexual women, both literally and symbolically, to offer 'Sex' as an activity and not as genitality, as workforce and profession with the purpose of surviving: I keep working as a commercial sex worker because sadly I do not have another way to make a living (Transvestite Woman 10).

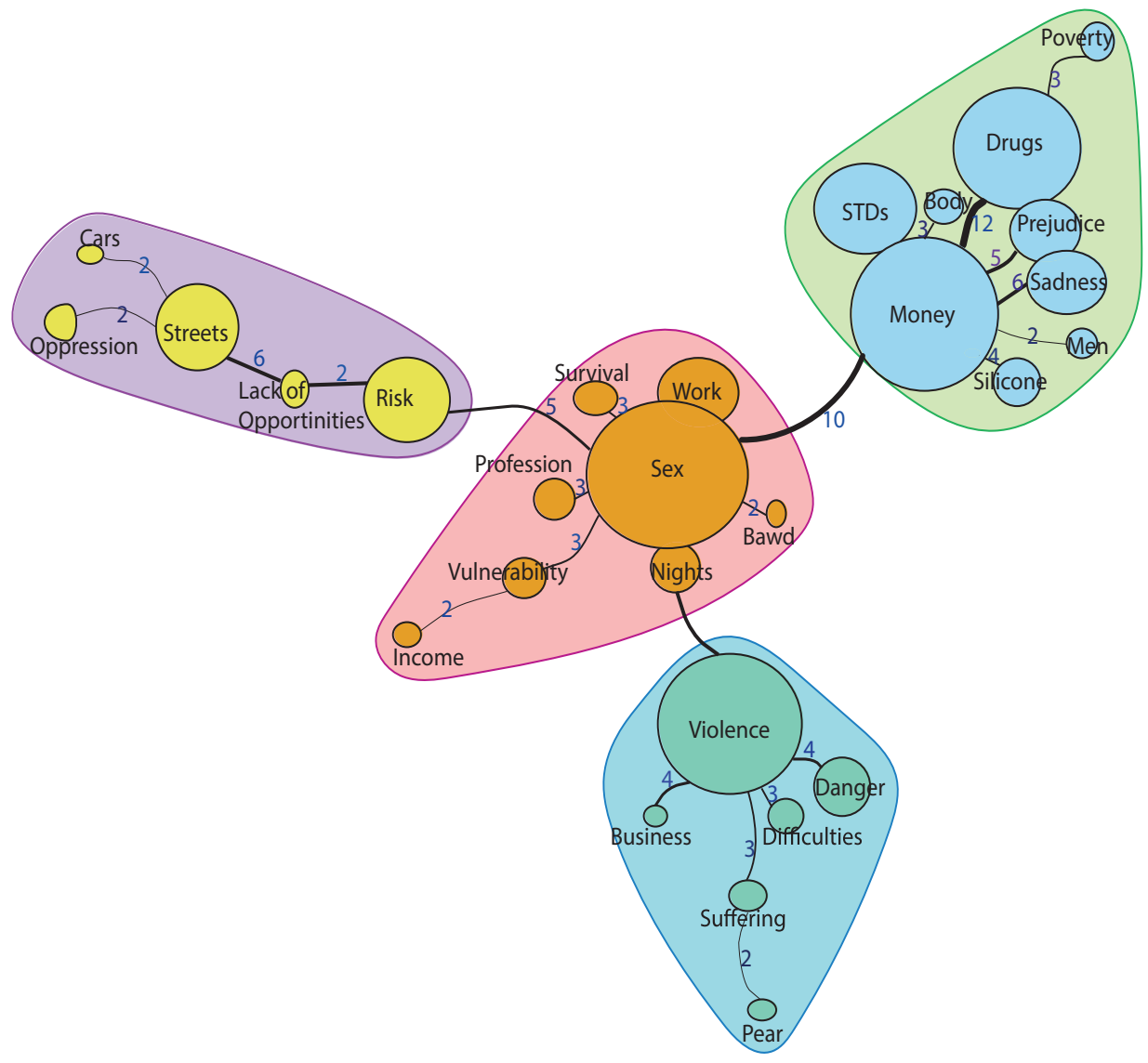

Figure 2. Analysis of the Similarity Between the Commercial sex work-Related Categories Between Transvestite and Transsexual Women in Florianópolis, Brazil, $2016(N=100)$. This figure verifies the three interconnected axis Risk, Violence, and Money with the axis Sex. It is important to recognize that a thicker line represent a stronger link among them. 
Regarding the axis 'Violence,' it shows a significant interconnection with the elements 'Vulnerability, 'Danger,' 'Street, which in turn shows a strong association with the concepts 'Night,' 'Risk,' and 'Suffering'. A possible interpretation may show that the phenomenon of violence in commercial sex work is linked to the context of 'Street' and 'Night' which reminds of danger, vulnerability, risk, and suffering:

It was here on this very Street around 10 p.m. The "Dude" bit me when I was leaving the car. This has happened three times in the last four months, it is another day at work if you walk the streets like us, you must get used to violence since the streets are dangerous like you have no idea. When night falls this turns into the gates of hell for us (Transvestite Woman 2).

Finally, in the graph of similarity, the axis 'Money' is significantly related to the term 'Sexually Transmitted Infection (STI), and it also overlaps with the terms 'Drugs' and 'Silicon.' A possible link to the associative strength between the concepts 'Money' and 'Sexually Transmitted Disease' would be the fact that commercial sex work is frequently related to the HIV virus, syphilis, and gonorrhea.

The women in the study candidly mention that depending on the money offered by the customer, they may relinquish the protection offered by the condom:

Most of my friends here are HIV positive because in commercial sex work you know you are exposed not only to AIDS but other STIs. If a customer shows up and offers more money for sex without condom and you need the money you end up doing it (Transsexual Woman 8).

The structural elements of the social representation of commercial sex work, conveyed in the prototypical analysis, in the statements, and in the graphic of similarities, explicitly show indications of life experiences and negative tendencies anchored in sayings based on violence, fears, risks, lack of recognition as citizens, and invalidation of the gender of the participants of the study.

\section{Discussion}

The social representation of commercial sex work was conveyed as a set of elements, life experiences and realities related to politics that separates them from social codes usually normal.

In other words, it is a space that takes individuals from their habitual contexts, since it puts them in deterritorialized places, like subversive basements and attics, to make them invisible.

The practice of commercial sex work must also be seen as a wider concept where other ways of living and being can arise; commercial sex work is not a reduced state for sexual practices and transgressions (Spivak, 2010; Vieira, 2015).

The scenarios and universes of urban sexual practices linked to commercial sex work of transvestite and transsexual women associate their image to the Liquid Modernity as proposed by Bauman (2001); that is, as a mythical and allegorical body where other differences are denied and can become ingrained in a society that has difficulty dealing with urban transformations which alter the feminine condition and its attributes. The complex activity developed while gathering the data for this study seems to be covered by 
many urban senses and elements, which pervade the daily reality (Mayorga, 2011). What is more, it is of paramount importance to stress the fact that such elements are not static/ definite but perceptions that overlap and produce dialogue while they disappear from the pleasure that derives from money, love, sex, drugs, and risk.

When reading between the lines of the prototypical analysis developed, the 'Highway' and 'Battle Field' (the streets) are metaphorical areas where the participants on the study establish collaborations and networks that vary according to each interaction and its context.

In this complex area of redefining its legal-social meaning, commercial sex work emerges as one, if not the only, working opportunity, showing the harsh reality these women face. There is an intensification of institutional violence always present in society (Kulick, 2008; Silva et al., 2016).

Certainly, the streets and their unwritten codes, organization, and survival work as the background in which family, affection, work, and institutional violence become stronger and reach different configurations.

From the same perspective, the content of the elements of the representations and their narratives were enough to convey the complexity of the situations that transsexual and transvestite commercial sex workers deal with on a daily basis.

Violence is stressed as a phenomenon of complex causes which involves several dimensions of the human experience. Violence is probably the most concentric element of the core of social representation in commercial sex work.

Such a phenomenon becomes decisive in modern times since it heightens violence in the public eye (Souza, Malvasi, Signorelli, \& Pereira, 2015; Silva et al., 2016). It can be said that the investigation has shown how in day-to-day-life, violence is a constant risk that can be manifested at any moment in different ways.

It is also safe to say that violence against transvestite and transsexual women is rising at a brutally accelerated rate. Nevertheless, its effect is not being well recorded due to different reasons. One of them is shown by the "Account on Violence Homo-lesbo-transphobia in Brazil". It has been noted that the census conducted by the Brazilian Institute of Geography and Statistics still does not ask specific questions on gender identity. This has caused a lack of official data on how many people identify themselves as transvestite and transsexual, who also deal with some type of violence.

Still, we can recognize it exists and leaves a mark in different and deadly ways (Souza, Malvasi, Signorelli, \& Pereira, 2015). Brazil is the country with the highest murder rates related to transvestite and transsexual women, which refers to trans-necro-politics.

Various reasons hide behind these systemic forms of violence that are extreme and symbolic; remembering what symbolisms say about a place that speaks of labels, prejudice and imprisonment of identity.

Consequently, the symbolic place of transsexual and transvestite women who are involved in commercial sex work is marked by social stigma, different types of violence, 
and stereotypes. Without defining violence as a homogeneous phenomenon, transsexual and transvestite women insist upon the specific violence they suffer, which seems to be especially 'designed' for them.

Therefore, violence is shown as the product of a moral order. It is created and nurtured within power, which repeats cultural behaviors that can mold and fracture the lives of those who are outside the traditional concepts of gender (Butler, 2003; Mbembe, 2008; Foucault, 2013).

Moreover, violence and drug consumption are socio-anthropological phenomena that have been present throughout human history. Both are sociopolitical issues that directly influence people's health, being leading causes of morbimortality worldwide.

These two social issues that designed the core of the social representation of commercial sex work are considered growing phenomena throughout society mainly in Latin-American countries such Brazil, Colombia, México and Costa Rica.

Unsurprisingly, trans women do not escape the historically constructed context of violence, prejudice and risk. For Brazilian (and other Latin American societies), the occupation that they perform is not only banned and illicit, but also morally unacceptable, exposing them to even vaster types of violence.

In fact, violence against transvestite and transwomen represents the legitimacy of the historical power of men over women and over everything else that escape the intelligibility of genders. Risk associated with physical, sexual and psychological violence, human traffic, robberies and others as humiliation and moral transgressions are among the most common hazards the participants in the study are exposed.

Another risk that the transvestites and female transsexuals are exposed to is the vulnerability to drug consumption, mainly to alcohol, marihuana and crack cocaine. These issues show the associations of social exclusion and the devastating levels of discrimination. This is directly associated with how trans-identified people have benefitted from unparalleled social progress compared to the general population, which itself may be a source of mental health problems that exacerbates substance abuse pressures.

Similarly, the way in which transvestite and transgender women experience commercial sex work shows how violence, drugs, danger, prejudice, sex, and money are crucial in the process of simplifying and regulating transvestite and transsexual women's identity (Mayorga, 2011).

Consequently, the social representations of commercial sex work and the elements that embody it compose a political language which aims for vindication (or acknowledgement) of the elemental rights of transgender commercial sex workers while reinforcing the need for appreciation of their condition of 'Trans People'.

Working under this 'intersectional' perspective allows us to stop trying to learn and analyze the reality of 'trans' commercial sex work through a particular concept but thinking of the categories of subject classification (Spivak, 2010). 
The 'trans experiences' in these categories are not detached from each other, much less could be combined as a ludic puzzle. They need to be thought of as articulate categories that co-exist in the same context.

Considering this, the elements that form the core of the social representations of commercial sex work overlap with social markers of differentiation; they have different meanings depending on the individual's location within power binding relationships.

The category of 'Trans-women or Transvestite' is therefore specific in its own way within historical configurations specific to gender relationships. Its meaning reaches new heights in the discussions of femininity.

The differences of these identities is not always understood: they are a mark of hierarchy and oppression. Nevertheless, we understand those discourses to be modern forms of power in economy, politics, and culture (Foucault, 2013; Santos, 2015).

Evidently, besides having a 'captive' citizenship, transsexual and transvestite women who engage in commercial sex work are subjected to power, inequality of class, gender, sexuality, and race. Therefore, it is not possible to think of an understanding of the lives of the women who participated on this study without considering gender identity and the construction of their own identities, thus hinting at the existence of more forms of vulnerability.

Therefore, the social representation of commercial sex work shows the need for a theoretical rescue of the dignity of any human being, along with the need to humanize the misunderstood population of trans-women and transvestites and acknowledging their citizenship (which nowadays is precarious).

Finally, similar analyses could be made for other status contexts, since the reality experienced by trans-identified women among Latin American countries is comparable to the one perceived in Brazil. Further studies are needed in order to solve the social, economic and public health needs of this population, focusing on the phenomena unveiled by the social representation of commercial sex work and in the life stories behind commercial sex workers.

\section{Final Considerations}

Experiencing commercial sex work is usually seen as a hybrid in each commercial sex worker's life, since it combines heavy burdens that form a varied profile.

Investing all their energies in their image, transvestite and transsexual women give commercial sex work a new and deeper meaning. Seduction games do not make violence, fear, risk or the will to survive go away behind the sex market and its inherent hazards.

Regarding dangers, we believe the commercial sex work archetype presents itself as hostile, and of paramount importance to understand both the transvestite and transsexual universe in which the streets are designed as the place of reference, even for those who look not only for customers but also for a place to be acknowledged. 
As the data was collected, the process of identity building of these women that are completely bound to the streets becomes quite fragile when considering the equation formed by being transsexual and transgender women, and the fact of being exposed to the streets.

Gender belittling is expressed in the subordination at their workplaces and in the commercial sex workers' interaction with their customers, and how the violence that they suffer is mocked. For this reason, this investigation's proposal is related to a critique that associates the fact of seeing violence -the most important component of the social representation, as a relationship of power and a violation of rights first represented as symbolic violence.

The preponderance of this train of thought avoids the implantation of intra-psychological roles aiming to avoid sexual and gender-based differences both at an empirical level and in relationships and social interactions, either subjective or related to the individual's identity.

\section{References}

Bauman, Z. (2001). Modernidade líquida. Rio de Janeiro: Zahar.

Butler, J. (2003). Problemas de gênero: Feminismo e subversão da identidade (R. Aguiar, Trad.). São Paulo: Civilização Brasileira.

Caravaca-Morera, JA., \& Padilha, MI. (2017). Bodies in motion: spaces, emotions and representations that (de)construct realities. Revista da Escola de Enfermagem da USP, 51(1), e03203. doi: 10.1590/s1980-220x2016036103203

Foucault, M. (2013). Arqueologia do saber. Tradução de Luiz Felipe Baeta Neves. 8. ed., Rio de Janeiro, Ed. Forense Universitária.

Jodelet, D. (2001). Representações sociais: um domínio em expansão. In D. Jodelet (Ed.), As representações sociais. Rio de Janeiro: EdUERJ.

Kulick, D. (2008). Travesti: prostituição, sexo, gênero e cultura no Brasil. (Trad. Cesar Gordon). Rio de Janeiro: Editora Fiocruz.

Longaray, D., \& Ribeiro, P. (2016). Travestis e transexuais: corpos (trans)formados e produção da feminilidade. Revista Estudos Feministas, 24(3), 761-784. doi: 10.1590/1806-9584-2016v24n3p761

Mbembe, A. (2008) Necropolitics. Public Culture, 15(1), 11-40.

Mayorga, C. (2011). Cruzando fronteiras: prostituição e imigração. Cadernos Pagu, (37), 323-355. doi: 10.1590/S0104-83332011000200014

Moscovici, S. (1976). La psychanalyse, son image et son public. Paris: PUF.

Moscovici, S. (2003). Representações Sociais: investigações em psicologia social. Rio de Janeiro: Vozes.

Santos, D. (2015). A biopolítica educacional e o governo de corpos transexuais e travestis. Cadernos de Pesquisa, 45(157), 630-651. doi: 10.1590/198053142970 
Silva, G., Souza, E., Sena, R., Moura, I., Sobreira, M., \& Miranda, F. (2016). Situações de violência contra travestis e transexuais em um município do nordeste brasileiro. Revista GaúchadeEnfermagem, 37(2), e56407.doi:10.1590/1983-1447.2016.02.56407

Souza, M., Malvasi, P., Signorelli, M., \& Pereira, P. (2015). Violência e sofrimento social no itinerário de travestis de Santa Maria, Rio Grande do Sul, Brasil. Cadernos de Saúde Pública, 31(4), 767-776. doi: 10.1590/0102-311X00077514

Spivak, G. (2010). Pode o subalterno falar?. Belo Horizonte, Ed. UFMG.

Vieira, M. (2015). Deslocamentos femininos e prostituição. Revista Estudos Feministas, 23(2), 629-632.

Villela, V., \& Monteiro, S. (2015). Gênero, estigma e saúde: reflexões a partir da prostituição, do aborto e do HIV/aids entre mulheres. Epidemiol. Serv. Saúde, 24(3), 531-540.

Recibido: 21 de setiembre de 2017

Aceptado: 02 de agosto de 2018 